\title{
Furosemide and acute renal failure
}

\author{
V. BORIRAKCHANYAVAT \\ M.B., M.R.C.P.
}

\author{
M. VONGSTHONGSRI \\ M.D.
}

\begin{abstract}
Summary
High dose of intravenous furosemide $(2 \mathrm{~g} / 24 \mathrm{hr})$ was given to six patients with acute renal failure due to leptospirosis. The results, based on urine flow, changes in serum creatinine and creatinine clearance, were compared with a control group of eight patients with the same disease and comparable degree of renal failure. Excellent diuresis was observed following furosemide therapy but renal function and the clinical course of the disease were unaltered. The duration of renal failure was the same in both groups.
\end{abstract}

\section{Introduction}

The benefit of furosemide (Frusemide B.P.) in acute renal failure is controversial. While it has been shown by a retrospective study that furosemide shortened the oliguric phase of renal failure (Cantarovich et al., 1973), in recent studies it failed to increase renal blood flow in both clinical and experimental acute renal failure (Epstein, Schneider and Befeler, 1975; Ufferman et al., 1975). Because of the difference in degree and aetiology of renal failure, it would be difficult on clinical grounds to evaluate the effect of furosemide on the course of the disease. Critical evaluation would require a controlled clinical trial in patients with renal failure of the same aetiology and severity. The authors now report a series of six patients with renal failure due to leptospirosis who were treated with high-dose furosemide. The results were compared with another group of leptospirosis patients with a comparable degree of renal failure.

\section{Patients and method}

The effects of high doses of furosemide were assessed in six patients with acute renal failure due to leptospirosis. The clinical data of these patients (cases 1 to 6) are shown in Table 1. The patients were admitted to hospital 4 to 8 days after the onset of illness. Blood urea nitrogen (BUN) varied from 92 to $130 \mathrm{mg} / \mathrm{dl}$ (mean \pm s.e.mean, $111 \cdot 3 \pm 5 \cdot 3$ ) and the serum creatinine varied from 5.0 to $7.4 \mathrm{mg} / \mathrm{dP}$ (mean \pm s.e.mean, $6 \cdot 3 \pm 0 \cdot 4$ ). There was jaundice in all the patients with the total bilirubin ranging from $\omega$ 7.7 to $20.0 \mathrm{mg} / \mathrm{dl}$ (mean \pm s.e.mean, $13.2 \pm 1.9$ ) The urine volume varied from 330 to $550 \mathrm{ml} / 24 \mathrm{hr}$ (mean \pm s.e.mean, $426 \cdot 7 \pm 36 \cdot 3$ ). After a control period, intravenous furosemide $(500 \mathrm{mg})$ was started on the second day of admission at 6-h? intervals. The dose was gradually reduced when the serum creatinine began to fall; this was tapered and finally discontinued within 7 to 8 days. Apponpriate intravenous electrolyte solution was admins:tered hourly to replace the hourly urine and $\mathrm{m}$ sensible loss. Twenty-four-hr urine was collecteds daily for volume, electrolytes and creatinine. Serumo electrolytes, BUN and serum creatinine were deter mined daily. Creatinine clearance was calculated $\stackrel{\mathbb{Q}}{\circ}$ All patients had acute tubular necrosis and inter- $\overrightarrow{\vec{\theta}}$ stitial nephritis and received conventional treatmen $\bar{B}$ for leptospirosis (Sitprija and Evans, 1970). No dialysis was required.

Eight patients with acute renal failure of compar $=0$ able severity due to leptospirosis were selected from the files and served as a control group. These patientso were hospitalized 4 to 7 days after the onset of ill ness. They had acute tubular necrosis and interstitial nephritis and received only conventiona treatment without diuretic; none had dialysis. The? clinical data of this control group (cases 7 to 14) upon admission are shown in Table 1 . BUN ranged? from 89 to $121 \mathrm{mg} / \mathrm{dl}$ (mean \pm s.e.mean, 104 $\pm 4 \cdot 6$ ), N serum creatinine ranged from 5.0 to $7.5 \mathrm{mg} / \mathrm{dr}^{\circ}$ (mean \pm s.e.mean, $6 \cdot 2 \pm 0.3$ ) and the total bilirubin from 8.4 to $21 \cdot 2 \mathrm{mg} / \mathrm{dl}$ (mean \pm s.e.mean, $13 \cdot 1 \pm 1 \cdot 7) . \omega$ Using Student's $t$-test showed there was no difference between the two groups with respect to BUN, serumo creatinine and urine volume upon admission (Table 1).

The clinical course of the two groups was compared with attention to urine flow, serum creatinine and creatinine clearance. 
TABLE 1. Clinical data

\begin{tabular}{|c|c|c|c|c|c|c|c|}
\hline Patient & $\begin{array}{c}\text { Age } \\
\text { (years) }\end{array}$ & Sex & BUN (mg/dl) & $\begin{array}{l}\text { Serum } \\
\text { creatinine } \\
(\mathrm{mg} / \mathrm{dl})\end{array}$ & $\begin{array}{c}\text { Serum } \\
\text { bilirubin } \\
(\mathrm{mg} / \mathrm{dl})\end{array}$ & $\begin{array}{l}\text { Urine volume } \\
(\mathrm{ml} / 24 \mathrm{hr})\end{array}$ & $\begin{array}{l}\text { Period of } \\
\text { serum } \\
\text { creatinine } \\
\text { elevation } \\
\text { (day) }\end{array}$ \\
\hline \multicolumn{8}{|c|}{ Furosemide group } \\
\hline $\begin{array}{l}1 \\
2 \\
3 \\
4 \\
5 \\
6\end{array}$ & $\begin{array}{l}34 \\
53 \\
26 \\
40 \\
42 \\
64\end{array}$ & $\begin{array}{l}\mathbf{M} \\
\mathbf{M} \\
\mathbf{M} \\
\mathbf{M} \\
\mathbf{M} \\
\mathbf{M}\end{array}$ & $\begin{array}{r}96 \\
118 \\
92 \\
121 \\
111 \\
130\end{array}$ & $\begin{array}{l}5 \cdot 0 \\
5 \cdot 7 \\
6 \cdot 1 \\
6 \cdot 7 \\
7 \cdot 1 \\
7 \cdot 4\end{array}$ & $\begin{array}{r}12 \cdot 2 \\
14 \cdot 3 \\
9 \cdot 4 \\
20 \cdot 0 \\
15 \cdot 4 \\
7 \cdot 7\end{array}$ & $\begin{array}{l}550 \\
350 \\
330 \\
430 \\
390 \\
510\end{array}$ & $\begin{array}{l}12 \\
12 \\
13 \\
11 \\
13 \\
10\end{array}$ \\
\hline \multicolumn{3}{|c|}{ Mean \pm s.e. mean } & $111 \cdot 3 \pm 5 \cdot 3$ & $6 \cdot 3 \pm 0 \cdot 4$ & $13 \cdot 2 \pm 1 \cdot 9$ & $426 \cdot 7 \pm 36 \cdot 3$ & $11 \cdot 8 \pm 0 \cdot 6$ \\
\hline $\begin{array}{r}7 \\
8 \\
9 \\
10 \\
11 \\
12 \\
13 \\
14\end{array}$ & $\begin{array}{l}24 \\
34 \\
61 \\
45 \\
42 \\
36 \\
26 \\
50\end{array}$ & $\begin{array}{l}\mathbf{M} \\
\mathbf{M} \\
\mathbf{M} \\
\mathbf{F} \\
\mathbf{M} \\
\mathbf{M} \\
\mathbf{M} \\
\mathrm{M}\end{array}$ & $\begin{array}{r}100 \\
110 \\
98 \\
120 \\
89 \\
94 \\
102 \\
121\end{array}$ & $\begin{array}{l}5 \cdot 0 \\
5 \cdot 3 \\
5 \cdot 6 \\
6 \cdot 0 \\
6 \cdot 5 \\
6 \cdot 8 \\
7 \cdot 0 \\
7 \cdot 5\end{array}$ & $\begin{array}{r}9 \cdot 8 \\
10 \cdot 5 \\
10 \cdot 2 \\
8 \cdot 4 \\
9 \cdot 4 \\
18 \cdot 6 \\
16 \cdot 7 \\
21 \cdot 2\end{array}$ & $\begin{array}{l}350 \\
410 \\
400 \\
610 \\
520 \\
450 \\
340 \\
420\end{array}$ & $\begin{array}{r}9 \\
10 \\
11 \\
14 \\
11 \\
13 \\
10 \\
12\end{array}$ \\
\hline \multicolumn{3}{|c|}{$\begin{array}{l}\text { Mean } \pm \text { s.e. mean } \\
t \text {-test }\end{array}$} & $\begin{array}{c}104 \pm 4.6 \\
0.4>P>0.3\end{array}$ & $\begin{array}{c}6.2 \pm 0.3 \\
0.9>P>0.8\end{array}$ & $\begin{array}{c}13 \cdot 1 \pm 1 \cdot 7 \\
P>0.9\end{array}$ & $\begin{array}{l}437.5 \pm 31.6 \\
0.9>P>0.8\end{array}$ & $\begin{array}{c}11.8 \pm 0.5 \\
0.6>P>0.5\end{array}$ \\
\hline
\end{tabular}

\section{Results}

\section{Urine volume}

The initial urine volume in the control group varied from 340 to $610 \mathrm{ml} / 24 \mathrm{hr}$ averaging $437.5 \mathrm{ml} / 24 \mathrm{hr}$ (Table 1). The urine flow gradually increased, reaching a maximum 5 to 8 days after admission. The maximum urine flow ranged from 3600 to 4300 $\mathrm{ml} / 24 \mathrm{hr}$ with a maximum urine sodium excretion between 246 and $415 \mathrm{mEq} / 24 \mathrm{hr}$.

In the furosemide group excellent diuretic response was observed. After intravenous furosemide there was a prompt increase in urine flow which further increased reaching a maximum within 4 to 7 days. The maximum urine volume ranged from 6600 to $14520 \mathrm{ml} / 24 \mathrm{hr}$ with maximum sodium excretion between 992 and $1656 \mathrm{mEq} / 24 \mathrm{hr}$.

\section{Serum creatinine}

Figure 1 showed the changes of serum creatinine in the course of the disease. In the control group, serum creatinine continued to rise after admission in seven out of eight patients. The rise was gradual, reaching the peak 2 to 4 days after admission. In one patient, there was no increase in serum creatinine. In all cases the serum creatinine returned to the normal level 9 to 14 days after admission with a mean of $11 \cdot 3$ days (Table 1 ).

In the treated group, after administration of the furosemide, serum creatinine continued to rise in two patients. In four patients there was a decrease in serum creatinine (Fig. 1). The serum creatinine re- turned to normal 10 to 13 days after admission. The period of creatinine elevation averaged 11.8 days (Table 1). Statistically there is no difference in duration of serum creatinine elevation among the two groups $(0.6>P>0.5)$.

\section{Creatinine clearance}

In the control group creatinine clearance was available in only five patients, and this ranged from $2 \cdot 1$ to $6.3 \mathrm{ml} / \mathrm{min}$. The rise in clearance was gradual during the first 5 days. Later, there was a steady rise in creatinine clearance reaching the level of 70 to 85 $\mathrm{ml} / \mathrm{min}$ within 12 to 14 days after admission.

In the treated group, creatinine clearance upon admission varied from 1.9 to $6.5 \mathrm{ml} / \mathrm{min}$. Increase of creatinine clearance following treatment was observed in three patients. In the remainder the clearance was unchanged. Creatinine clearances between 72 and $82 \mathrm{ml} / \mathrm{min}$ were attained 13 to 14 days after admission.

Based on the duration of serum creatinine elevation and the rate of increment of creatinine clearance there appeared to be no difference in the course of renal failure between the two groups of patients.

\section{Discussion}

In this study, acute renal failure in leptospirosis served as a unique clinical model for evaluation of the effects of high doses of furosemide. The condition was of the same aetiology and pathology and, in both groups, impaired renal function based on 


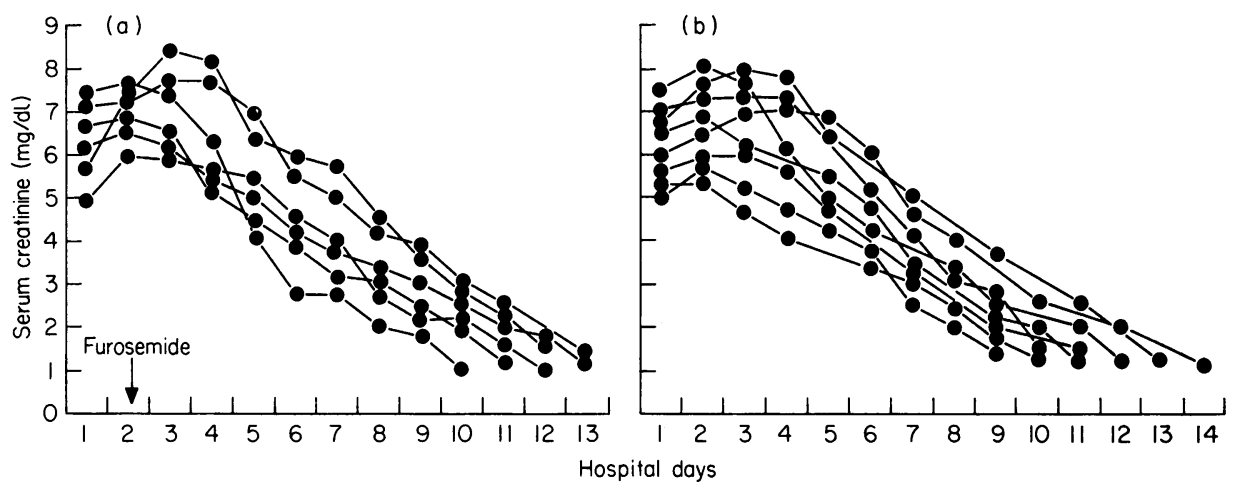

FIG. 1. Changes in serum creatinine in the two groups of patients, (a) furosemide group; (b) control group.

serum creatinine, and jaundice were of comparable degree. There was no difference between the two groups when statistically analysed (Table 1). Although the number of cases is small, it is apparent that within this range of renal failure with serum creatinine between 5.0 and $7.5 \mathrm{mg} / \mathrm{dl}$, which is a narrow range, profuse diuresis can be obtained with the use of high doses of furosemide $(2 \mathrm{~g} /$ day $)$. The serum creatinine either increased or decreased. Creatinine clearance increased in three patients and remained unchanged in three on the day following furosemide administration. Since a gradual increase in creatinine clearance was also noted in the control group, the increased clearance in a few patients of the treated group need not be the effect of furosemide but would rather reflect the natural course of the disease. The period of creatinine elevation was the same in both groups $(0.6>P>0.5)$. Therefore, despite profuse diuresis, renal function and the clinical course of renal failure were unchanged.

Although furosemide does not alter the clinical course of renal failure, its advantage in the management of patients should be recognized. With the increased urine flow, fluid can be given more liberally. Fluid restriction is often poorly tolerated by a patient. With an increased fluid allowance, additional calories can be provided parenterally or orally, and medicines can be more easily ingested. It is perhaps worth mentioning that increased urine flow helps in relieving psychological tension of both the patient and the physician involved. However, if should be pointed out that when diuresis is profound, hourly fluid replacement according to the urine flow may pose a problem of circulatory overo load. In this regard the dose of furosemide should be reduced. Whether or not the patients with a more severe degree of renal failure would benefit from high-dose furosemide cannot be answered from this study alone, and warrants further investigation.

\section{Acknowledgments}

Frusemide was supplied by Hoechst Thai Ltd. The author are grateful to Miss Supanee Kavalee for her secretarias assistance.

\section{References}

Cantarovich, F., Galli, C., Benedetti, L., Chena, C. Castro, L., Correa, C., Perez loredo, J., Fernandezọ. J. C., Locatelli, A. \& Tizado, J. (1973) High dose frusemide in established acute renal failure. British Medica? Journal, 4, 449.

Epstein, M., Schneider, N.S. \& Befeler, B. (1975) Effect of intrarenal furosemide on renal function and intrarena?. hemodynamics in acute renal failure. American Journal of Medicine, 58, 510.

SitPriJA, V. \& EVANS, H. (1970) The kidney in human leptospirosis. American Journal of Medicine, 49, 780.

UfFerman, R.C., Jaenike, J.R., Freeman, R.B. \& Pabico, R.D (1975) Effects of furosemide on low-dose mercurie chloride acute renal failure in the rat. Kidney International 8, 362 . 